\title{
Gıda Kontaminantlarının Analizine Yönelik Elektrokimyasal Biyosensör Uygulamaları
}

\author{
Merve MUTi ISTEK (iD ${ }^{*}$, Selda BULCA (iD) 1 \\ ${ }^{1}$ Aydın Adnan Menderes Üniversitesi, Söke Meslek Yüksekokulu, Aydın \\ ${ }^{2}$ Aydın Adnan Menderes Üniversitesi, Mühendislik Fakültesi, Gıda Mühendisliği Bölümü, Aydın \\ Geliş Tarihi (Received): 18.08.2021, Kabul Tarihi (Accepted): 12.12.2021 \\ $\square$ Sorumlu Yazar (Corresponding author*): merve.muti@adu.edu.tr \\ (C) +902565111427 吾 +902565111430
}

\section{ÖZ}

Patojenik bakteriler, ağır metal iyonları, mikotoksinler, antibiyotikler ve pestisitler gibi gıda kirleticilerinin sebep olduğu çeşitli kontaminasyonlar, gıda güvenliği ve insan sağlığı için ciddi tehditler oluşturmaktadır. Gıda kontaminasyonu sonucunda gıda güvenliği sorunlarının sık sık ortaya çıkması, hem tüketiciler hem de gıda endüstrisi için endişe kaynağı haline gelmiştir. Gıda kontaminasyon problemlerini kontrol altına almak ve önlemek adına kalitatif ve kantitatif birçok tespit yöntemi geliştirilmiştir. Bu yöntemler arasında Gaz Kromatografisi (GC) ve Yüksek Performanslı Sıvı Kromatografisi (HPLC) gibi analiz yöntemleri sayılabilir. Fakat bu yöntemlerin maliyetli ve karmaşık olması, beceri gerektirmesi, zaman alması, numunelerin ön işlemden geçirilmesi gibi dezavantajları nedeniyle biyosensör teknikleri son yıllarda gıda kontaminasyon analizlerinde diğerlerine kıyasla daha fazla tercih edilen yöntemler olmuştur. Bu çalışmada son yıllarda gıda kontaminasyon analizleri için geliştirilmiş elektrokimyasal biyosensör uygulamaları araştırılmış ve çeşitli bilgilere yer verilmiştir.

Anahtar Kelimeler: Elektrokimyasal biyosensör, gıda analizi, kontaminasyon

\section{Electrochemical Biosensor Applications for Food Contaminants Analysis}

\begin{abstract}
Various contaminations caused by food contaminants such as pathogenic bacteria, heavy metal ions, mycotoxins, antibiotics and pesticides pose serious threats to food safety and human health. The frequent occurrence of food safety problems as a result of food contamination has become a concern for both consumers and the food industry. Many qualitative and quantitative detection methods have been developed to control and prevent food contamination problems. These methods include analysis methods such as Gas Chromatography (GC) and High-Performance Liquid Chromatography (HPLC). However, due to the disadvantages of these methods such as being costly and complex, requiring skill, taking time, and pre-processing the samples, biosensor techniques have become more preferred methods in food contamination analysis in recent years compared to others. In this study, electrochemical biosensor applications developed for food contamination analysis in recent years have been investigated and various information are given.
\end{abstract}

Keywords: Electrochemical biosensor, food analysis, contamination 


\section{GíRiş}

Gıdada beklenmedik veya tanımlanmamış fiziksel, kimyasal veya biyolojik kirleticilerin varlığı gıdanın güvenliğini tehdit eden unsurlardandır. Gıda güvenliği, halk sağlığı için hayati bir konudur ve tüm dünyadaki insanlar için günlük bir kaygıdır (Erkmen, 2010; Alahi ve Mukhopadhyay, 2017; Nardi ve ark., 2020). Gıda tedarik zincirinde gıda güvenliği olayları sıklıkla bildirilmekte ve sayıları giderek artmaktadır (Soon ve ark., 2020). Bununla birlikte sürekli artan dünya nüfusu, küresel gıda tedarik sisteminin bütünlüğüne yönelik ciddi bir zorluk olarak görülmekte ve bu nedenle, daha yüksek gıda gereksinimlerini öngörmek için üretimi artırmaya intiyaç duyulmaktadır (Paepe ve ark., 2019).

Fiziksel, kimyasal ve biyolojik kirleticilerle kontamine olmuş gıdalar, bazı hastalıkları insan vücuduna iletebilir ve bu hastalıklar insan hayatına mal olabilecek boyutlara ulaşabilir. Bu yüzden gıdaların toksik bileşiklerle kontamine olma olasılığına özel dikkat gösterilmelidir. Bu bileşikler gıdada tesadüfen mevcut olabilecekleri gibi çeşitli şekillerde de türetilebilirler (Belitz ve ark., 2009; Güler ve Can, 2017; Nardi ve ark., 2020).

Gıdalarda toksin kaynakları; gıdaların doğal bileşim ögeleri ve gıdalarda kontaminasyon sonucu oluşan bileşikler olmak üzere iki sınıflandırma altında incelenebilir. Gıdalardaki doğal toksik maddeler bitkisel ve hayvansal kaynaklı olarak ikiye ayrılırken, kontaminasyon sonucu oluşan toksik madde kaynakları; (i) mikroorganizmaların toksik metabolitleri, (ii) çevresel kirleticiler, (iii) bitki koruyucu ajanların kalıntıları, (iv) gıda katkı maddeleri, (v) ambalaj malzemesi ürünlerinin bileşenleri, hayvancılık artıkları ve gıdaların işlenmesi sırasında oluşabilen toksik bileşikler olarak sıralanabilir (Belitz ve ark., 2009; Saldamlı, 2017). En tehlikeli kirleticiler, mikroorganizmalar tarafından üretilenler olup, biyolojik kaynak yok edildikten sonra bile gıdada kalan toksinlerdir. Pestisit kalıntıları veya ağır metaller gibi diğer kirleticiler genellikle modern gıda kaynaklarında iyi kontrol edilir. Doğal olarak oluşan toksik bileşenler genellikle, tek tek bileşenlere duyarlı olabilen tüketicilerin durumları dışında, gıdalarda normal olarak yenildiğinde zararlı etkiler üretemeyecek kadar küçük dozlarda bulunur. Gıda katkı maddeleri veya yeni yiyecekler, toksikolojileri iyi çalışıldığından ve kullanım koşulları sıkı bir şekilde kontrol edildiğinden genellikle en az tehlike arz edenlerdendir (Williams, 2012).

Kirleticilerle ilgili endişelerin kapsamı göz önüne alındığında, gıda kalitesi, güvenliği ve adil ticaretini sağlamak için yeterli ve güvenilir tespit ve analiz yöntemlerine ihtiyaç vardır. Ortaya çıkan gıda tehlikelerini tespit etme ve analiz etme yöntemlerinin geliştirilmesi ve onaylanması sürekli çalışmayı gerektiren uygulamalardır. Herhangi bir gıda bileşeninin analizinde olduğu gibi, gıda tehlikelerinin analizi için seçilebilecek bir dizi metodolojik yaklaşım ve teknik vardır.

Gıda matrisinin karmaşıklığı da dahil olmak üzere, numunenin polarite, hidrofobiklik, uçuculuk, termal stabilite ve kimyasal reaktivite gibi özellikleri ve şüpheli kirletici seviyesi gibi birçok faktör, yöntem seçimini etkiler. Gıda matrisinin karmaşıklığı ve numune özellikleri, ekstraksiyon, ayırma, saptama ve niceleme tekniklerinin seçimini önemli ölçüde etkiler. Analitik yöntemin doğruluğu, kesinliği, özgüllüğü ve duyarlılığı da önemli parametrelerdir. Gıda tehlikelerinin analizine yönelik yöntemler, niteliksel, yarı niceliksel veya niceliksel olabilir. Tarama yöntemleri olarak da bilinen kalitatif ve yarı kantitatif yöntemler, genellikle aynı aileye ait bir veya daha fazla kontaminantın varlığı için çok sayıda numuneyi test etmek için kullanılır. Nitel yöntemler, belirli bir tayin sınırında veya üzerinde belirli kirletici maddelerin varlığını tespit ederken, yarı kantitatif yöntemler, tespit edilen bir kirletici maddenin konsantrasyonunun yaklaşık değerini verir. Bu yöntemler, İnce Tabaka Kromatografisi (TLC), enzim inhibisyonu ve immünolojik testler gibi teknikleri içerir. Gıda kirleticilerinin ve kaIıntılarının eşzamanlı kantitasyonu ve yapısal tanımlaması için, Gaz Kromatografisi (GC) ve Yüksek Performanslı Sıvı Kromatografisi (HPLC) ve immünolojik analizler, kullanılan analitik yöntemlerdir (Liang ve ark., 2016; Nielsen, 2017; Kaneko ve ark., 2018; Zhou ve ark., 2020). Membran tabanlı, yanal akış şeridi, kemilüminesans, floresans ve biyosensörler de dahil olmak üzere immünolojik analizler, antijen $(\mathrm{Ag})$ ve antikorun (Ab) spesifik kombinasyonuna dayanan yeni, hızlı ve yüksek verimli bir analiz stratejisidir ve gıda kontaminasyon analizlerinde sıklıkla kullanılmaktadır. $\mathrm{Bu}$ yöntemlerden biyosensör uygulamaları hızlı analiz süresi, seçimlilik, ucuzluk gibi avantajları nedeniyle son yıllarda giderek yaygınlık kazanmaktadır (Nielsen, 2017; Doğan ve Koç, 2018; Kozitsina ve ark., 2018; Evtugyn ve Hianik, 2019; Feng ve ark., 2019; Pan ve ark., 2020).

\section{BIYOSENSÖRLER}

Sensör, fiziksel ve kimyasal miktarları ölçer ve bunları bir elektrik sinyaline dönüştürür. Sensörler, bir enerji biçimini başka bir tür enerjiye dönüştüren bir tür dönüştürücüdür (Alahi ve Mukhopadhyay, 2017). Hazırlama ve uygulamada nispeten basit ve ucuz olan bu cihazlar, gaz ve sıvı fazlarındaki maddelerin tanımlanmasına ve belirlenmesine olanak tanır. Çeşitli teknolojik işlemlerde geniş bir uygulama alanı bulurken otomatik ve uzaktan modlarla da çalışabilir (Thyparambil ve ark., 2017; Kuchmenko ve Lvova, 2019). 
İlk biyosensör 1950'li yıllarda L.C. Clark tarafından glikoz oksidaz enzimi ile $\mathrm{O}_{2}$ elektrodunun birleştirilmesiyle geliştirilmiş ve kandaki glikoz miktarını ölçmek için kullanılmıştır. Günümüzde nano bilim ve biyolojik bilim gibi birçok alandaki gelişmelerin sonucu olarak, biyosensörlere çok sayıda yenilik entegre edilerek daha yüksek performans özellikleri kazanmış ve hızı bir gelişim göstermiştir (Boz ve ark., 2017; Tüylek, 2017; Ye ve ark., 2020).

Biyosensör, biyolojik, kimyasal veya biyokimyasal sinyali ölçülebilir ve işlenebilir elektriksel sinyale dönüştürebilen, kimyasal veya fiziksel transdüser ile birleştirilmiş biyolojik algılama materyali içeren bir cihazdır ( $\mathrm{Li}$, 2006; Nogués ve ark., 2016). Genel olarak biyosensörler, biyoloji, fizik, kimya, biyokimya ve mühendislik gibi birçok bilimsel alanın bilgisini multidisipliner bir yöntemle kullanarak hem modern elektronik tekniklerin proses yeteneklerini hem de biyolojik moleküllerin veya sistemlerin seçicilik özelliklerini birleştirerek geliştirilen biyoanalitik cihazlar olarak bilinir (Kurbanoglu ve ark., 2020). Biyosensör tanımı gereği, Şekil 1'de gösterildiği gibi, biyo-algılama (biyoreseptör) ve dönüştürücü (transdüser) bölümlerinden oluşur. Algılama kısmı biyolojik olarak türetilmiş moleküllere dayanır ve dönüştürücü kısmı, fizyokimyasal reaksiyonu ölçülebilir sinyallere dönüştürür (Jayan ve ark., 2020). Biyoreseptörler, biyosensör gelişiminde önemli bir rol oynar ve analitin ölçümler için sensöre bağlanmasından sorumludurlar. Bu yüzden sadece analite duyarlı ve ölçüm sırasında diğer moleküllerden etkilenmeyecek şekilde kararlı yapıda olmalıdırlar (Boz ve ark., 2017). Biyoreseptörler; i) enzimler, ii) afinite reseptörleri (antijenler / antikorlar, DNA probları), iii) hücreler ve hücre organelleri, iv) yapay reseptörler (moleküler olarak baskılı polimerler, biyomimetikler, aptamerler), v) bakteriyofaj şeklinde kategorize edilebilir (Alahi ve Mukhopadhyay, 2017; Kozitsina ve ark., 2018; Wu ve ark., 2019). Reseptör katmanının biyosensör yüzeyine immobilizasyonu fiziksel sorpsiyon, polimer matrikste immobilizasyon, kovalent bağlanma, afinite immobilizasyon yöntemleri gibi farklı şekillerde gerçekleştirilebilir (Kozitsina ve ark., 2018). Biyosensörler farklı sinyal dönüştürücü tipine göre de elektrokimyasal, optik, piezoelektrik, kalorimetrik ve manyetik biyosensörler olmak üzere sınıflandırılabilirler. Transduserler, biyoreseptörler ile analit arasında gerçekleşen reaksiyonları ölçer ve fiziksel bir sinyale dönüştürürler ( $\mathrm{Li}, 2006$; Xu ve Ying, 2011; Tüylek, 2017).

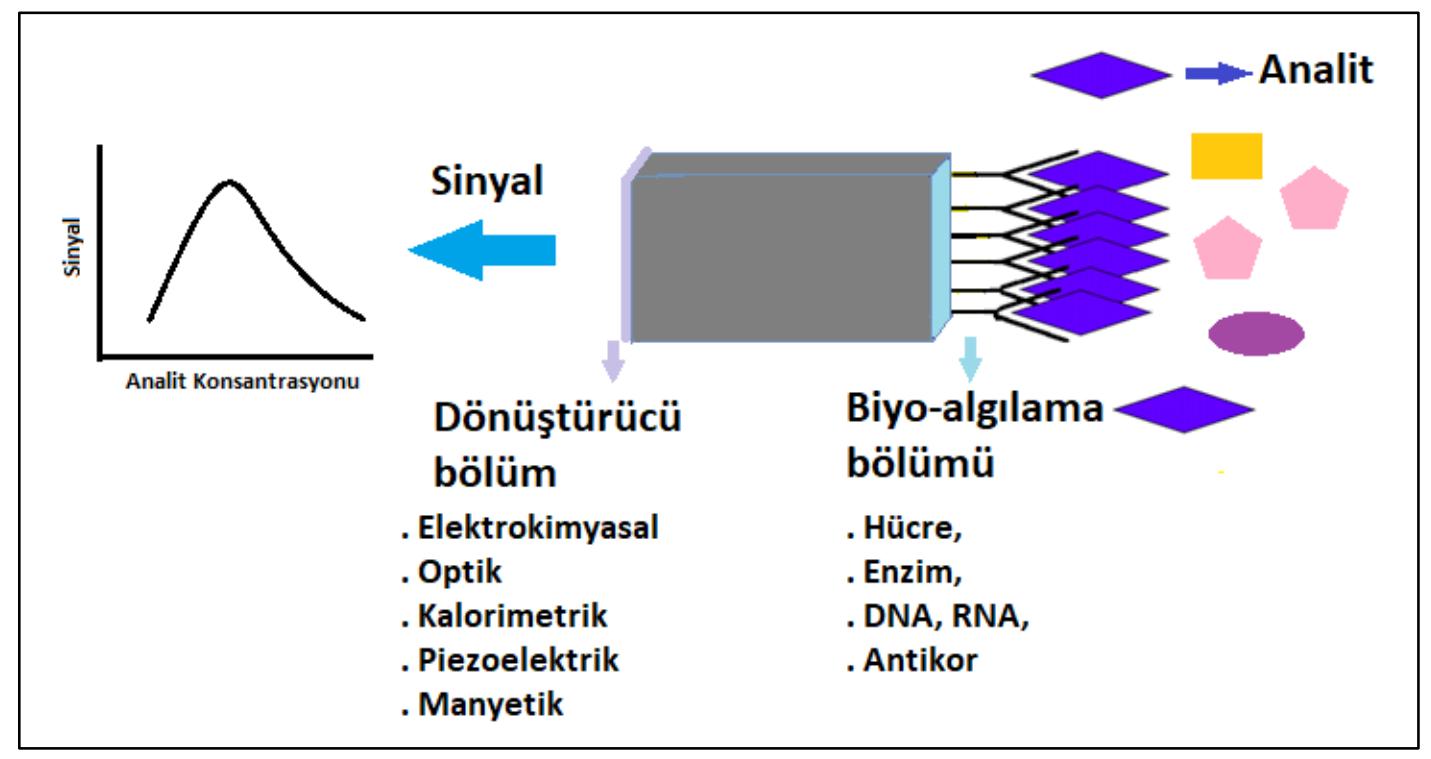

Şekil 1. Tipik bir biyosensörün yapısı

\section{Elektrokimyasal Biyosensörler}

Elektrokimyasal biyosensörler, diğer biyosensörlerle kıyaslandığında en eski ve en gelişmiş biyosensörlerdir (Li, 2006). Elektrokimyasal biyosensörler, algılama elektrodu ile analitin etkileşmesi sonucu arayüzde gerçekleşen kimyasal reaksiyonlardan kaynaklanan akım veya potansiyel değişikliğini tespit eder. Analiz edilen parametrelere göre potansiyometrik, amperometrik, voltametrik, kondüktometrik ve impedimetrik türleri gibi farklı elektrokimyasal biyosensörler mevcuttur (Alahi 
ve Mukhopadhyay, 2017; Caglayan ve ark., 2020; Jayan ve ark., 2020). Potansiyometrik biyosensörler, biyolojik algılama elementi içeren bir elektrokimyasal hücre içerisinde genellikle ya bir ürünün aktivitesi ya da elektrokimyasal reaksiyondaki bir tepkenin aktivitesinin gerilimini ölçmeye dayalıdır (Li, 2006). Amperometrik biyosensörler, belirli bir elektrot potansiyeli altında elektrik akımına veya elektrik akımındaki değişikliğe dayalı numunelerin tespitini gerçekleştirir. Voltametrik biyosensörler, analit ile etkileşen elektrot yüzeyi arasında, elektrokimyasal reaksiyon meydana geldiğinde, uygulanan potansiyelin bir fonksiyonu olarak akımı kaydeden elektroanalitik yöntemdir. Diferansiyel-Puls Voltametri (DPV) ve Dönüşümlü Voltametri (CV) gıda alanında yaygın olarak kullanılan voltametrik tekniklerdendir (Geleta ve ark., 2018; Kurbanoglu ve ark., 2020). Kondüktometrik biyosensörler, elektrotanalit arayüzünde gerçekleşen biyokimyasal reaksiyonlar sonucunda değişen iletkenliğin ölçümünü esas alır (Bahadır ve Pagano, 2014). İmpedimetrik biyosensörlerde, elektrot yüzeyine biyomoleküllerin bağlanması, elektriksel iletkenliği bloke edici bir tabaka oluşturarak direnç artışına neden olabilir. İmpedimetrik biyosensörler, biyomoleküler tanıma olaylarının etiket kullanmadan doğrudan tespit edilmesini sağlar (Geleta ve ark., 2018).

Elektrokimyasal algılama yöntemleri, dolaylı algılama stratejileri kullanılarak elektroaktif olmayan hedeflere başarıyla uygulanır. Bu yöntemler genellikle elektrot yüzeyinde bulunan bir moleküler tanıma tabakası ile etkileşime girdiğinde hedefin varlığında/yokluğunda bir elektroaktif probun elektrokimyasal sinyalindeki değişiklikleri kaydeder. Elektrot modifikasyonları, antikorlar, enzimler, peptitler, aptamerler ve moleküler baskılı polimerler (MIP) gibi biyoreseptörleri ve biyomimetik reseptörleri içerir (Moro ve ark., 2019).

Çeşitli biyosensörler arasında elektrokimyasal biyosensörler, düşük tayin sınırı, yüksek tekrarlanabilirlik, hızlı yanıt, düşük maliyet, minyatürleştirilebilme, taşınabilme, kolay çalışılabilme gibi çeşitli avantajlar sunar (Alahi ve Mukhopadhyay, 2017; Evtugyn ve Hianik, 2019; Jiang ve ark., 2019; Li ve ark., 2019; Wu ve ark., 2019; Chen ve ark., 2020; Jemmeli ve ark., 2020; Wang ve ark., 2020).

\section{ELEKTROKIMYASAL BIYOSENSÖRLERIN GIDA KONTAMINANTLARI ANALIZINDE KULLANIL- MASI}

Elektrokimyasal biyosensörler, sağladıkları üstün özellikler ile geleneksel yöntemlerin ideal bir alternatifi haline gelmiştir. Bu yüzden elektrokimyasal biyosensörler, gıda analizleri başta olmak üzere günümüzde birçok analiz için kullanım alanı bulmaktadır ve geliştirilmektedir.

Gıda kontaminantlarının analizinde GC, HPLC, SıVı Kromatografisi-Kütle Spektrometresi (LC-MS), Polimeraz Zincir Reaksiyonu (PCR), ELISA gibi yöntemlerin yanı sıra elektrokimyasal biyosensörler, özellikle düşük tayin sınırına inebilmeleri, basit, hızlı, ekonomik olma gibi özellikleri sebebiyle kalıntıların hem tekli hem de çoklu tayininde tercih edilen yöntemlerdir (Nielsen, 2017; Geleta ve ark., 2018; Wu ve ark., 2019; Chen ve ark., 2020). Son yıllarda gıda kontaminatlarının analizine yönelik yapılmış olan elektrokimyasal biyosensör çalışmaları Tablo 1' de gösterilmiştir. 
Tablo 1. Gıda kontaminantlarının analizinde elektrokimyasal biyosensör uygulamaları

\begin{tabular}{|c|c|c|c|c|}
\hline Analit & Elektrot & Teknik & Tayin Sınırı & Kaynak \\
\hline E. coli & AuE & EIS & $102(\mathrm{kob} / \mathrm{mL})$ & $\begin{array}{l}\text { Wang ve ark., } \\
2020\end{array}$ \\
\hline E. coli & GCE & CV, DPV, EIS & 7 (kob/mL) & Li ve ark., 2020 \\
\hline E. coli & PGE & $\mathrm{CV}$, Amperometri & $30(\mathrm{kob} / \mathrm{mL})$ & $\begin{array}{c}\text { Güner ve ark., } \\
2017\end{array}$ \\
\hline E. coli & GCE & CV & $101(\mathrm{kob} / \mathrm{mL})$ & $\begin{array}{l}\text { Panhwar ve } \\
\text { ark., } 2019 \\
\end{array}$ \\
\hline E. coli & $\begin{array}{l}\text { Altın mikroelekt- } \\
\text { rot }\end{array}$ & EIS & $103(\mathrm{kob} / \mathrm{mL})$ & $\begin{array}{l}\text { Helali ve ark., } \\
2018\end{array}$ \\
\hline SEB & SPE & CV, DPV, EIS & $0,21 \mathrm{fM}$ & $\begin{array}{l}\text { Nodoushan ve } \\
\text { ark., } 2019\end{array}$ \\
\hline AFM1 & $\begin{array}{l}\text { AuE } \\
\text { AuE }\end{array}$ & DPV, EIS & $\begin{array}{l}8,62 \mathrm{ng} / \mathrm{L} \\
8,47 \mathrm{ng} / \mathrm{L}\end{array}$ & $\begin{array}{l}\text { Karapetis ve } \\
\text { ark., } 2018\end{array}$ \\
\hline Okratoksin A & SPE & DPV, EIS & $0,06 \mathrm{nM}$ & $\begin{array}{l}\text { Wang ve ark., } \\
2018\end{array}$ \\
\hline Kurşun & SPE & CV, DPV & $0,36 \mathrm{nM}$ & $\begin{array}{c}\text { Ding ve ark., } \\
2018 \\
\end{array}$ \\
\hline Civa & AuE & CV, EIS & $0,05 \mathrm{nM}$ & $\begin{array}{c}\text { Zhang ve ark., } \\
2017\end{array}$ \\
\hline İmidaklopridin & SPE & Kronoamperometri & $22 \mathrm{pmol} / \mathrm{L}$ & $\begin{array}{l}\text { Fernández ve } \\
\text { ark., } 2020 \\
\end{array}$ \\
\hline Malathion & SPE & CV, DPV, EIS & $0,06 \mathrm{pg} / \mathrm{mL}$ & $\begin{array}{l}\text { Aghoutane ve } \\
\text { ark., } 2020\end{array}$ \\
\hline $\begin{array}{l}\text { Profenofos } \\
\text { Forate } \\
\text { Isocarbophos } \\
\text { Omethoate } \\
\end{array}$ & SPE & CV, DPV & $\begin{array}{c}0,01 \mathrm{nM} \\
0,1 \mathrm{nM} \\
0,01 \mathrm{nM} \\
0,1 \mathrm{nM} \\
\end{array}$ & $\begin{array}{l}\text { Fu ve ark., } \\
2020\end{array}$ \\
\hline Aspartam & SPE & CV, DPV & $0,0076 \mathrm{nM}$ & $\begin{array}{l}\text { Le ve ark., } \\
2019\end{array}$ \\
\hline Sudan III & CPE & $\begin{array}{l}\text { CV, DPV, Kronokulo- } \\
\text { metri }\end{array}$ & $2,56 \mathrm{nM}$ & $\begin{array}{l}\text { Heydari ve } \\
\text { ark., } 2019\end{array}$ \\
\hline Bisfenol A & $\begin{array}{l}\text { Kağıt temelli } \\
\text { sensör }\end{array}$ & CV, SWV & $0,03 \mu \mathrm{M}$ & $\begin{array}{l}\text { Jemmeli ve } \\
\text { ark., } 2020 \\
\end{array}$ \\
\hline Kanamisin A & GCE & CV, EIS & $0,3 \mathrm{nM}$ & $\begin{array}{l}\text { Kulikova ve } \\
\text { ark., } 2020\end{array}$ \\
\hline Akrilamid & CPE & CV & $0,06 \mathrm{nmol} / \mathrm{L}$ & $\begin{array}{l}\text { Navarro ve } \\
\text { ark., } 2020\end{array}$ \\
\hline
\end{tabular}

AuE: Altın Elektrot; EIS: Elektrokimyasal Empedans Spektroskopisi; GCE: Camımsı Karbon Elektrot; CV: Dönüşümlü Voltametri; DPV: Diferansiyel Puls Voltametri; PGE: Kalem Grafit Elektrot; SEB: Stofilokokal Enterotoksin B; SPE: Perde Baskılı Elektrot; AFM1: Aflatoksin M1; CPE: Karbon Pasta Elektrot; SWV: Kare Dalga Voltametri

\section{Mikrobiyal Kontaminantlar ve Toksik Metabolitlerinin Analizine Yönelik Uygulamalar}

Gıda kaynaklı patojen kontaminasyonu dünya genelinde insan sağlığını tehdit etmektedir ve bu durum, patojenin erken tespitini önemli kılmaktadır (Wang ve ark., 2020). Gıda kaynaklı patojen olan Escherichia coli (E.coli) O157:H7'nin kalitatif ve kantitatif tespitinin yapıldığı bir çalışmada (Wang ve ark., 2020), manyetik tanecik temelli elektrokimyasal empedans immünolojik test yöntemi geliştirilmiştir. Çalışmada, E.coli O157:H7'nin yüksek duyarlılıkta tespiti, algılama elemanları olarak birbirine bağı altın elektrotları kullanan homojen bir manyetik tanecik tabanlı elektrokimyasal empedans sistemi ile gerçekleştirilmiştir. Sistem için elektrot modifikasyonundan ve numune matrisi adsorpsiyonundan kaçınılmıştır ve algılama duyarlılığı büyük ölçüde iyileştirilmiştir. Bu yöntemde E.coli O157:H7 için tayin sınırı mililitrede $10^{2} \mathrm{kob} / \mathrm{mL}$ olarak elde edildiği rapor edilmiştir. Ayrıca yöntem geleneksel ELISA metodu ile kıyaslandığında tayin sınırının üç kat daha düşük olduğu görülmüştür. E.coli O157:H7'nin tespitine dayalı bir diğer elektrokimyasal biyosensör önermesinde (Li ve ark., 2020), farklı teknikler kullanılmıştır. Elektrokimyasal biyosensör tasarımında 3D DNA yürüteç, yuvarlanan daire amplifikasyonu (RCA) ve hibridizasyon zincir reaksiyonu (HCR) aracılığıyla çoklu amplifikasyon stratejisi kullanılmıştır ve $E$. coli O157:H7'nin yüksek duyarlılıkta tespiti amaçlanmıştır. 
Çalışma sonucunda beklendiği gibi, E. coli O157:H7 testi için çoğu güncel yöntemden üstün olan önerilen çoklu amplifikasyon stratejisine dayalı olarak $7 \mathrm{kob} / \mathrm{mL}$ tayin sınırı ile yüksek bir duyarlılığa ulaşılmıştır. Güner ve ark. (2017), yaptıkları bir çalışmada ise E. coli O157:H7'nin saptanması için bir elektrokimyasal immünosensör geliştirmiş ve karakterize etmişlerdir. Geliştirilen bu immünosensör polipirol/altın nanoparti$\mathrm{kül} /$ çok duvarlı karbon nanotüp/kitosan hibrit biyonanokompozit modifiye kalem grafit elektroduna (PGE) dayanmaktadır. Bu hibrit biyonanokompozit platformu daha sonra anti-E coli O157:H7 monoklonal antikoru ile modifiye edilmiştir. Hazırlanan biyonanokompozit platformu ve immünosensör, CV kullanılarak karakterize edilmiştir. Geliştirilen elektrokimyasal immünosensörün oldukça duyarlı olduğu ve tayin sınırının 30 $\mathrm{kob} / \mathrm{mL}$ E. coli O157:H7 patojenik bakterinin tespitine izin verdiği açıklanmıştır. Panhwar ve ark. (2019), literatüre kazandırdığı bir diğer çalışmada, E. colı'nin hızlı saptanmasına ilişkin yenilikçi ve amino işlevli bir elektrokimyasal biyosensör rapor etmişlerdir. Fonksiyonelleştirilmiş $\mathrm{Fe}_{3} \mathrm{O}_{4}$ nanopartiküllere dayalı sensör, L-sistein ile modifiye edilmiş ve bakterileri tespit etmek için CV tekniği kullanıımıştır. Bu çalışmanın sonuçları, geleneksel, zaman alıcı ve daha pahalı laboratuvar tabanlı analizlerin zorluklarına alternatif çözüm üreten, sudan kaynaklanan mikrobiyal kontaminasyonun rutin izlenmesi için taşınabilir bir su sensörünün geliştirilmesine yönelik hedeflerin ilk adımını içermektedir. Tasarlanan biyosensörün, musluk suyu örneklerinden $E$ coli'yi tespit etmek için yüksek seçicilikte olduğu ve tayin sınırının $10^{1} \mathrm{kob} / \mathrm{mL}$ olarak hesaplandığı bildirilmiştir. Bir başka çalışmada (Helali ve ark., 2018), tavuk eti örneklerinde patojenik $E$. coli tespiti için elektrokimyasal biyosensör tasarlanmıştır. Dondurulmuş tavuk etinde E. coli K12, Elektrokimyasal Empedans Spektroskopisi (EIS) ve Yüzey Plazmon Rezonans (SPR) görüntüleme teknikleri kullanılarak araştırılmıştır. ÇaIışmada anti-E. coli antikoru ilk olarak fiziksel sorpsiyon tekniği ile altın yüzeyi üzerine immobilize edilmiş ve sonrasında anti- $E$. coli $\mathrm{K} 12$ antikorunun elektriksel ve optik özellikleri incelenmiştir. E. coli K12 bakterisinin
anti-E. coli antikor tabakası ile bağlanmasının iyi bir tekrarlanabilirlikle ölçüldüğü ve tayin sınırının $10^{3}$ $\mathrm{kob} / \mathrm{mL}$ olarak saptandığı bildirilmiştir. Bu tayin sınırının, enzime bağlı immünosorbent testi (ELISA) tekniğiyle elde edilen sonuçlardan daha iyi olduğu ifade edilmiştir. Ayrıca, geliştirilen biyosensörün, inoküle dondurulmuş tavuk etinde $E$. coli K12 saptaması için kullanıldığı rapor edilmiştir.

Dünya çapında en yaygın gıda kaynaklı patojenlerden biri, enzimler ve toksinler gibi sağlığımıza zararlı olabilecek enterotoksin, nörotoksin ve sitotoksin gibi çeşitli virülans faktörleri üreten Staphylococcus aureus'tur. $S$. aureus'un enterotoksijenik suşları tarafından salgılanan Stafilokokal enterotoksin B'nin (SEB) şiddetli gıda zehirlenmesine neden olan bakteriyel bir toksin olarak tespiti büyük önem taşımaktadır (Nodoushan ve ark., 2019). İndirgenmiş grafen oksit (rGO) ve altın nano kestaneler (AuNU'lar) ile modifiye edilmiş bir perde baskılı elektrot kullanarak (SPE) Nodoushan ve ark. (2019), SEB tayini için elektrokimyasal aptasensör geliştirmişlerdir. Geliştirilen sensör yüzeyine önce tek sarmallı DNA probu (ssDNA) immobilize edilmiş ve ardından spesifik aptamer, proba bağlanmıştır (dsDNA). SEB moleküllerinin varlığında, aptamer elektrot yüzeyinden ayrılmıştır ve elektrokimyasal sinyal oluşturucu uygulandıktan sonra hematoksilin ve DPV pik akımı kaydedilmiştir. Hematoksilin-DNA etkileşiminin interkalasyon mekanizması nedeniyle, aptamerin elektrot yüzeyinden ayrılması DPV pik akımını düşürmüştür ve kalibrasyon grafiğinden (pik akımı-SEB konsantrasyonu) faydalanarak SEB'nin ölçümü gerçekleştirilmiştir. Elektrot karakterizasyonu için CV ve EIS (Şekil 2) ayrıca alan emisyon taramalı elektron mikroskobu görüntüleme teknikleri kullanılmıştır. 5,0 ila 500,0 fM arasında geniş bir doğrusal aralık elde edildiği bildirilen çalışmada tayin sınırı 0,21 fM olarak hesaplanmıştır. Aptasensörün seçiciliği ve tekrarlanabilirliğinin tatmin edici olduğu belirtilmiş ve ticari ELISA kitiyle kıyaslandığında daha üstün performans gösterdiği ifade edilmiştir. 


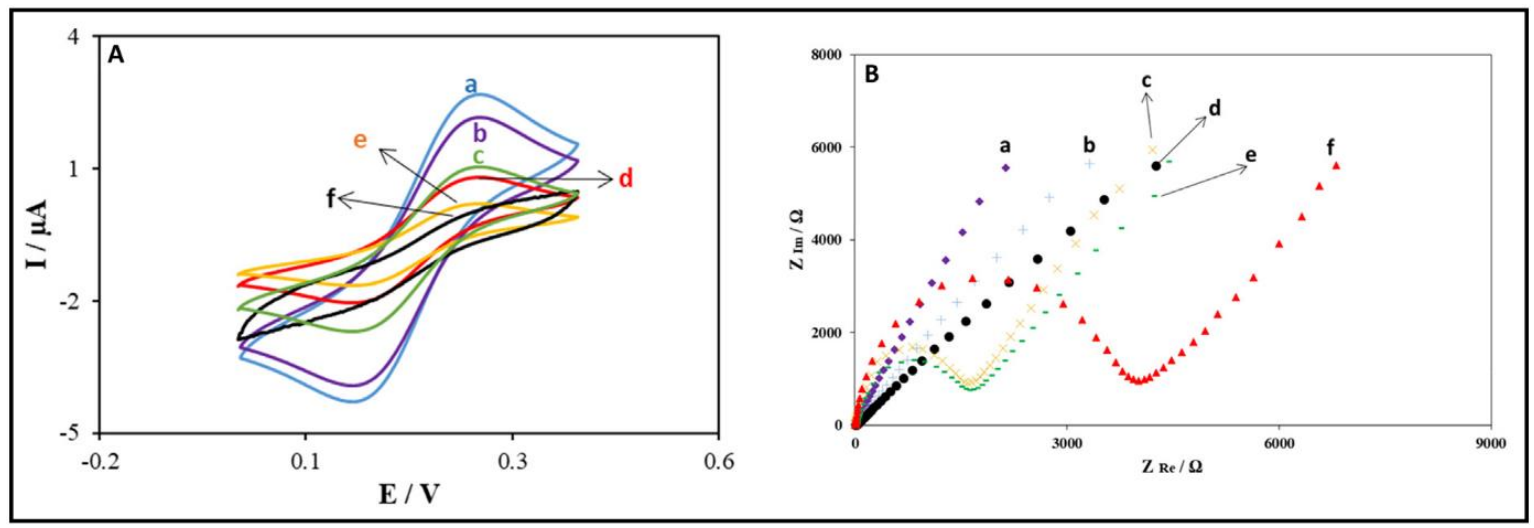

Şekil 2. (A) Adım adım aptasensör fabrikasyonunda $\mathrm{K}_{3}\left[\mathrm{Fe}(\mathrm{CN})_{6}\right]$ çözeltisi içinde alınmış dönüşümlü voltamogramlar; a. AuNUs/rGO/SPE, b. SPE/rGO, c. MCH/ssDNA/AuNUs/rGO/SPE, d. ssDNA/AuNUs/rGO/SPE, e. Yalın SPE elektrot, f. dsDNA/AuNUs/rGO/SPE;

(B) Modifiye edilmiş SPE elektrotların $1.0 \mathrm{M} \mathrm{KCl}$ içeren $5.0 \mathrm{mM} \mathrm{K}_{3}\left[\mathrm{Fe}(\mathrm{CN})_{6}\right]$ çözeltisi içinde alınmış Nyquist eğrileri; a. AuNUs/rGO/SPE, b. SPE/rGO, c. MCH/ssDNA/AuNUs/rGO/SPE, d. Yalın SPE elektrot, e. ssDNA/Au$\mathrm{NUs} / \mathrm{rGO} / \mathrm{SPE}$, f. dsDNA/AuNUs/rGO/SPE (Nodoushan ve ark., 2019)

Süt ürünlerindeki ana toksik faktörlerden biri, mantarlar tarafından üretilen ikincil metabolitler olan mikotoksinlerin konsantrasyonudur. İnsanlarda veya hayvanlarda hastalıklara ve hatta ölümlere neden olabilirler. Aflatoksin, mikotoksinlerin başlıca gruplarından biridir ve aflatoksin M1, aflatoksin B1'in (AFB1) doğal metabolitidir (Karapetis ve ark., 2018). Yapılan bir çalışmada, süt ürünlerinde önemli bir kirletici olan aflatoksin M1 (AFM1) tespiti için elektrokimyasal biyosensör geliştirilmesi amaçlanmıştır. DNA aptamerlerinin immobilizasyon yöntemine ve tespit yöntemine bağlı olarak, aptamer bazlı biyosensörlerin AFM1 saptanması için duyarlılığının karşılaştırmalı bir analizi gerçekleştirilmiştir. İlk sensörde amino ile modifiye edilmiş DNA aptamerleri, dördüncü nesil (G4) poliamidoamin dendrimerlerinin (PAMAM) yüzeyine immobilize edilmiş, ikinci sensörde ise biyotin ile modifiye edilmiş aptamerler, altın yüzeyinde kimyasal olarak emilen nötravidin tabakasına immobilize edilmiştir. Çalışma kapsamında ölçüm metodu olarak EIS ve DPV kullanılmıştır. İlk durumda tayin sınırı 8,47 ng/L olarak belirlenmiştir. İkinci durumda tayin sınırı, yaklaşık 8,62 ng/L olarak saptanmıştır ve elde edilen iki değerin de süt ve süt ürünlerinde izin verilen AFM1 sınırlarının altında olduğu görülmüştür. Geliştirilen aptasensörler, \%78'den daha iyi geri kazanımla karıştırılmış süt numunelerinde doğrulanmıştır (Karapetis ve ark., 2018).

Aspergillus ve Penicillium cinslerinin mantar türleri tarafından salgılanan, gıdaları kirleten yaygın mikotoksinlerden biri olan Okratoksin A (OTA), pirinç, yer fistığı, kahve, mısır gibi çeşitli yiyecekleri kolayca kolonileştirebilir ve insan bedenine girerek kana ve anne sütüne geçebilir (Wang ve ark., 2018). OTA tespiti için yapılan bir çalışmada (Wang ve ark., 2018), yeni bir aptamer sensörü, konak-konuk (host-guest) yarışma moduna göre geliştirilerek, terminalinde metilen mavisi (MB) ile modifiye edilen aptamer, p-siklodekstrin (-CD) ile konak-konuk tanıma yoluyla altın elektrotun yüzeyine sabitlenmiştir. Daha sonra sinyal amplifikasyonu için $\mathrm{MoS}_{2}$ nano levha / altın nanopartikül nanokompozitler kullanılmıştır. OTA mevcut olduğunda, MB-aptamer konfigürasyonunun dikey doğrusaldan G-dörtlüsüne dönüştüğü böylece kendisini elektrot yüzeyine yaklaşamaz hale getirdiği ve MB-aptamer redoks akımında bir azalmaya neden olduğu bildirilmiştir. Serbest ferrosen karboksilik asitin boş bölgeyi tanıyıp işgal edebildiği ve akımda sinyaller üretebildiği ve bunun da "oranlı" etki ile sonuçlandığı ifade edilmiştir. İkili sinyal prensibine dayanan bu yöntemin, OTA tespiti için tasarlanan diğer biyosensörlere kıyasla gerek doğrusal aralık gerek tayin sınıı parametrelerinde üstünlük sağladığı belirtilmiştir. OTA için tayin sınırı 0,06 nM olarak tespit edilerek tasarlanan biyosensörün yüksek duyarlılık ve özgüllüğü ile biyolojik numunelerde OTA'nın yüksek verimli tespiti için önemli bir platform sağlayacağı öngörülmüştür (Wang ve ark., 2018).

\section{Çevresel Kirleticilerin Analizine Yönelik Uygulamalar}

Gıdalardaki ağır metal kirliliği, ekolojik sistem ve insan sağlığına ciddi tehdit oluşturmaktadır. Aralarında cıva $(\mathrm{Hg})$, kurşun $(\mathrm{Pb})$, kadmiyum $(\mathrm{Cd})$, arsenik (As), çinko $(\mathrm{Zn})$, nikel $(\mathrm{Ni})$, bakır $(\mathrm{Cu})$ gibi metallerin bulunduğu ağır metallerin atom ağırlığı 63,5 ile 200,6 arasındadır ve özgül ağırlığı 5,0'dan büyüktür. Bir ağır metal olan Kurşun (II) iyonu $\left(\mathrm{Pb}^{2+}\right)$ kontaminasyonu gida zinciri boyunca birikebilir ve halk sağlığına ciddi bir tehdit oluşturabilir. $\mathrm{Bu}$ nedenle, $\mathrm{Pb}^{2+}$ 'yı izlemek için hızlı, 
hassas ve seçici biyosensörlerin geliştirilmesine yönelik çok sayıda araştırma çalışması yapılmıştır (Yang ve ark., 2017). Ding ve ark. (2018), $\mathrm{Pb}^{2+}$ iyonunu saptamak için bir elektrokimyasal aptasensör geliştirmişlerdir. Yapılan bu çalışmada altın nanopartiküllerin iyi elektriksel iletkenlik özelliklerinden faydalanmak için polipirolle kompoze edilmiş ve elde edilen kompozit akım sinyalini yükseltmek için perde baskılı karbon elektrodun modifiye edilmesinde kullanılmıştır. Hazırlanan bu modifiye elektrot yüzeyine tek sarmallı DNA immobilize edilerek $\mathrm{Pb}^{2+}$ iyonunun da tek sarmallı DNA'ya tutunması sağlanmıştır. Bağlanmalar, $-0,2 \mathrm{~V}$ ile $0,6 \mathrm{~V}$ arasında gerilim uygulanarak CV ile karakterize edilmiştir. Elektrokimyasal prob olarak hekzasiyanoferratın kullanıldığı çalışmada aptamer ile $\mathrm{Pb}^{2+}$ arasındaki etkileşim 0,10 V'de (Ag / AgCl'ye karşı) DPV ile izlenmiştir. $\mathrm{Pb}^{2+}$ varlığında aptamer, bir $\mathrm{G}$-dörtlü oluşturarak pik akımını artıımıştır. Bu yöntemle, $\mathrm{Pb}^{2+}$ iyonu, 0,5-10 nM aralığında yüksek hassasiyet ve seçicilikle 0,36 nM'lik düşük tayin sınırı ile tespit edilebileceği gösterilmiştir.

Güçlü bir toksin olan cıva, proteinler ve enzimlerle bağlanarak hayati doku ve organlarda birikebilir, bu da hücre fonksiyonlarında anormallik ve pek çok hastalıkla sonuçlanır. Bu yüzden cıva kirleticilerinin yüksek duyarlıııta tespiti büyük önem taşımaktadır (Zhang ve ark., 2017). Yapılan bir çalışmada (Zhang ve ark., 2017), Cıva (II) $\left(\mathrm{Hg}^{2+}\right)$ iyonlarını tespit etmek için ultra hassas, kolay ve yeniden kullanılabilir bir elektrokimyasal biyosensör tasarımı bildirilmiştir. Tasarımda DNA probunun tamamlayıcısı olan tiyol işaretli DNA 1 (5'-SH-AAAAAAAAAAAAAAA-CGCGCG-5'), tiyol ile $\mathrm{Au}$ arasındaki afiniteden yaralanılarak altın elektrot (AuE) yüzeyine modifiye edilmiştir. Sonra modifiye elektrot, altın nanopartikül (AuNP) ile modifiye edilmiş olan raporcu DNA 3 (5'-SH-CGCGCGCGCGCG-5') ile inkübe edilmiştir. Bu şekilde DNA 3, DNA 1'in ucuna bağlanmıştır. $\mathrm{Hg}^{2+}$ iyonu DNA 2 (5'TTTTTTTTTTTTTTTT-3') ile inkübe edilmiş ve DNA1+DNA2 ile modifiye edilmiş olan elektrot $\mathrm{Hg}^{2+}$ iyonu ile inkübe edilmiş olan DNA 2 çözeltisine daldırılmıştır. DNA 1 ortamda $\mathrm{Hg}^{2+}$ bulunduğunda, $\mathrm{Hg}^{2+}$ ile $\mathrm{T}$ bazı arasındaki bağlanma nedeniyle DNA 2, doğrusallıktan hairpin özellik kazanır ki bu da daha az miktarda prob DNA'nın (DNA 2) DNA 1 ile hibritleşmesine sebep olur. Bu çalışmada MB indikatör olarak kullanılmıştır. DNA 3-DNA 2-DNA 1 modifiye AuE, $5 \mathrm{mg} / \mathrm{mL}$ $M B$ içeren ve $M B$ içermeyen durumda $100 \mathrm{nM} \mathrm{Hg}^{2+}$ çözeltisine daldırılmış ve MB içeren durumda daha yüksek bir indirgenme sinyali elde edildiği rapor edilmişir. Elektrokimyasal sinyaldeki değişimin $\mathrm{Hg}^{2+}$ konsantrasyonu ile doğru orantılı olduğu bildirilen çalışmada, biyosensörün elektrokimyasal davranışları EIS ve CV ile değerlendirilmiştir. Gerçek su numunelerine de uygulanan biyosensörün geniş doğrusal aralık, yüksek duyarlııı, diğer yöntemlerle karşılaştırıldığında 0,05nM gibi çok daha düşük tayin sınırı sergilemekle birlikte üstün seçicilik ve mükemmel stabilite gösterdiği bildirilmiştir.

\section{Bitki Koruyucu Kalıntılarının Analizine Yönelik Uygulamalar}

Bitki koruyucu ajanlar pestisitler; herbisitler, fungusitler ve insektisitler olmak üzere üç ana gruba ayrılabilirler. Pestisitler, kansere, üreme ve merkezi sinir sistemlerinde sorunlara ve nihayetinde sürekli maruz kalma söz konusu ise ölüme neden olabilecek herhangi bir canlı için en toksik kimyasal maddeler arasındadır. Maruz kalanların çoğu tarım işçileri ve aynı zamanda meyve ve sebze tüketicileridir. Bu nedenle bu tür numunelerde ve atık sularda kapsamlı pestisit kontrolleri yapılmalıdır (Fernández ve ark., 2020). Neonikotinoid ailesine ait, haşerelerin kontrolü, tohum tedavisi ve sistemik bir insektisit olarak yaygın kullanılan, toprakta uzun süreli kalıcı etkiye sahip bir pestisit olan İmidaklopridin (IMD) tespiti için Fernández ve ark. (2020), bir elektrokimyasal biyosensör tasarlamışlardır. Yapılan çalışmada, AuNP ile modifiye edilmiş perde baskıı karbon elektrotlar (AuNP-SPCE) üzerinde IMD pestisitinin elektrokimyasal tayini için doğrudan rekabetçi bir immünosensör ilk kez rapor edilmiştir. Kendi kendine elde edilen spesifik monoklonal antikorlar, AuNP'lerin biyofonksiyonelleştirme yeteneklerinden yararlanılarak AuNP-SPCE üzerinde immobilize edilmiştir. Biyosensör tasarımında, numunedeki serbest IMD, antikorlar tarafından tanınması için horseradish peroksidaz (IMD-HRP) ile konjuge IMD ile rekabet etmiştir. Bundan sonra, 3,3',5,5'- Tetrametilbenzidin (TMB), HRP tarafından enzimatik olarak oksitlenerek SPCE'nin yüzeyinde indirgenmiştir. Bu süreç, IMD miktarı ile ters orantılı olan ilişkili bir katalitik akım (analitik sinyal) vermiştir. Analitik sinyali etkileyen ana parametreler optimize edilmiştir ve biyosensörün iyi bir hassasiyete (\%6 RSD ile tekrarlanabilirlik), doğruluğa (\%6'lık göreceli hata), kararlılığa (bir aya kadar), seçiciliğe ve oldukça düşük bir tayin sınırı (22 pmol/L) ile yüksek duyarlılığa, yasaların izin verdiği maksimum seviyelerin altında tayin yeteneği olan geniş bir yanıt aralığına (50-10000 $\mathrm{pmol} / \mathrm{L}$ ) sahip olduğu iddia edilmiştir. IMD saptanması için musluk suyu ve karpuz örneklerine de uygulanan elektrokimyasal immünosensör, IMD analizi için resmi laboratuvarlarda kullanılan referans yöntem olan HPLC-MS/MS ile istatistiksel testlerle de doğrulanmıştır. 
Malathion (MAL), bir organofosforlu (OP) böcek ilacldır. Ciddi sağlık ve çevre sorunları oluşturabilen bir kolinesteraz inhibitörüdür (Aghoutane ve ark., 2020). MAL'ın zeytin meyvelerinde ve zeytinyağlarında izlenmesini iyileştirmek için yapılan bir çalışmada (Aghoutane ve ark., 2020), moleküler baskılı polimere (MIP) dayalı yeni, ucuz, seçici ve oldukça hassas bir elektrokimyasal sensör geliştirilmiştir. Bu elektrokimyasal biyosensör tasarımı perde baskılı altın elektrotlar (Au-SPE) kullanılarak fonksiyonel monomer olarak akrilamidin ve kalıp molekül olarak MAL'in polimerizasyonu ile oluşturulmuştur. Elektrot yüzeyinin morfolojisi, Taramalı Elektron Mikroskobu (SEM) ve Atomik Kuvvet Mikroskobu (AFM) ile incelenmiştir. Geliştirilen MIP sensörünün elektrokimyasal karakterizasyonu, CV, DPV ve EIS teknikleriyle gerçekleştirilmiştir. Gerçek numunelerde de MAL tespiti için başarıyla uygulanan biyosensörün dinamik konsantrasyon aralığı $(0,1$ $\mathrm{pg} / \mathrm{mL}-1000 \mathrm{pg} / \mathrm{mL}$ ) ve tayin sınırı $0,06 \mathrm{pg} / \mathrm{mL}$ olarak bildirilmiştir.

Organofosforlu pestisitler (OPP'ler), hastalıkları, zararIıları ve yabani otları kontrol etmek için tarımda yaygın olarak kullanılmaktadır. Organofosforlu pestisitlerin büyük çoğunluğu kullanım sırasında çevreye ulaşıp daha sonra besin zincirine girerek insan sağlığı açısından büyük tehlike oluşturmaktadır. Bu nedenle, kalıntıların izlenmesi için duyarlıı̆̆ı yüksek bir algılama yöntemi geliştirmek önem kazanmaktadır (Fu ve ark., 2020). Tarım ürünlerinde sıklıkla bulunan, OPP'lerin ana bileşenleri profenofos, phorate, isocarbophos ve omethoate tespiti için Fu ve ark. (2020) elektrokimyasal bir aptasensör geliştirmişlerdir. Yöntemde, elektrokimyasal sinyalin ölçülmesi için bir anahtar görevi gören hairpin yapısında bir aptamer tasarlanmıştır. 5 've 3' uçları sırasıyla amino grupları ve redoks probu ferrosen $(\mathrm{Fc})$ ile modifiye edilmiştir. Aptameri bir amid bağı oluşturarak immobilize etmek için grafen oksit ve kitosan (GO-chit) içeren bir nanokompozit kullanılmıştır. Bir OPP eklendikten sonra, hairpin yapısının açımasıyla aptamere bağlanmaktadır ve böylece Fc elektrot yüzeyinden uzaklaştırılmıştır. Hedef konsantrasyon, Fc tarafından üretilen akım ölçülerek belirlenmiştir. Hedef konsantrasyon ne kadar yüksekse, Fc o kadar uzaktadır ayrıca elektrot yüzeyi ve akım daha küçüktür. Sinyal ve hedef konsantrasyon arasındaki ilişki incelenerek, gerçek numunelerdeki OPP kalıntılarının yarı kantitatif analizi gerçekleştirilmiştir. Profenofos, forate, isocarbophos ve omethoate için aptasensörün elektrokimyasal performansı, bağlanma kapasitesi ve tepkisi de çalışılmıştır. Elde edilen tayin sınırları ise sırasıyla 0,01, 0,1, 0,01 ve 0,1 nM kadar düşüktür.

\section{Gıda Katkı Maddelerinin Analizine Yönelik Uygulamalar}

Şeker ve kalori alımını azaltmak için gıda endüstrisi tarafından, aspartam (ASP), sodyum siklamat (CYC), asesülfam potasyum (ACS-K) ve sodyum sakarin (SAC) gibi yapay tatlandırıcıların kullanıldığı birçok türde gıda ürünü üretilmektedir. Yapay tatlandırıcıların olası hastalıklarla ilişkisine ilişkin araştırmalar, çeşitli insan kanseri türleri ile yapay tatlandırıcılar arasında bir ilişkiyi kanıtlamamıştır fakat hayvan çalışmaları ASP'nin sıçanlar ve fareler için kanserojen bir ajan olduğunu doğrulamıştır. Yapay tatlandırıcıların insan sağlığı üzerindeki etkisine ilişkin tartışmalar olduğu için, kabul edilebilir günlük ASP alımının 40 mg/kg vücut ağırlığı olması önerilmektedir. Bu nedenle, gıda ürünlerinde gıda katkı maddesi olarak kullanılan yapay tatlandırıcıların doğru ve duyarlı bir şekilde belirlenmesi için geliştirilecek analizler, önemli bir araştırma çalışmasını temsil etmektedir (Le ve ark., 2019). Bu doğrultuda Le ve ark. (2019), aspartamın tespitine dayalı bir elektrokimyasal biyosensör geliştirmişlerdir. ASP ve kafeik asit (CAF) içeren bir pH 7,0 fosfat tampon çözeltisinde CV yönteminin kullanıldığı çalışmada işlem görmemiş elektrotların aksine, bir homopolimer poli (CAF) ve bir kopolimer poli (CAF-ASP) oluşumuna bağlı olarak önceden anodize edilmiş SPCE'larda iki farklı redoks piki gözlenmiştir. Polimer filmle modifiye edilmiş elektrotların özellikleri, AFM, SEM, Fotoelektron Spektroskopisi (XPS) ve su temas açısı tekniği ile karakterize edilmiştir ve elektrokimyasal olarak indüklenen polimerizasyon mekanizmaları tartışılmıştır. Poli (CAF-ASP) 'den gelen mevcut yanitlar, ASP belirlemesi için kullanılmıştır ve DPV ile 0,05 mM ile $10 \mathrm{mM}$ arasında doğrusal bir dinamik aralıkla tayin sınırı $0,0076 \mathrm{mM}$ olarak bulunmuştur. Standart ekleme yöntemi kullanılarak iki meşrubatta ASP tayini için, hazırlanan elektrotlarla yapılan çalışmada Coca-Cola ve Coca-Cola Zero için sırasıyla \%103,0-106,7 ve \%97,3106,4 aralığında geri kazanımlar elde edilmiştir. Önerilen biyosensör yöntemini doğrulamak adına sonuçlar HPLC ile de karşılaştırılmış ve aralarında iyi bir uyuşma olduğu gösterilmiştir.

Yapının bir parçası olarak bir azo grubu $(-\mathrm{N}=\mathrm{N}$-) içeren bir dizi sentetik yağda çözünen renklendirici olan Sudan boyaları (Sudan I, Sudan II, Sudan III ve Sudan IV) genellikle plastik ve tekstilde kullanılır. Malzemeler genellikle parlak kırmızı renkleri, renk haslıkları ve düşük fiyatları nedeniyle gıda katkı maddesi olarak kullanılmaktadır. Bununla birlikte, bu sentetik renklendiriciler, olası insan kanserojeni olarak sınıflandırılmıştır ve günlük alımları Dünya Sağlık Örgütü tarafından belirlenen maksimum izin verilen seviyeleri aşarsa, tüketici 
sağlığı için potansiyel bir risk oluşturmaktadır. Bu nedenle, gıda ürünlerinde yaygın kullanımları Avrupa Birliği tarafından yasaklanmıştır ve gıda maddelerindeki Sudan boyalarının incelenmesi önem kazanmıştır. Bu doğrultuda gıda numunelerinde Sudan boyalarının tespiti için farklı yöntemler geliştirilmiştir (Heydari ve ark., 2019). Yapılan bir çalışmada (Heydari ve ark., 2019), gıda numunelerinde Sudan III'ün tespiti için çok değişkenli optimizasyon yöntemleriyle desteklenen duyarlı bir elektrokimyasal tekniğin uygulaması sunulmuştur. Söz konusu çalışmada ilk olarak çinko oksit nanopartiküller (ZnONP) sentezlenmiş ve X-Işını Difraktometresi (XRD) ve SEM teknikleri ile karakterize edilmiştir. Daha sonra nanopartiküllerle, karbon pasta elektrot (CPE) yüzeyi modifiye edilmiş ve böylece modifiye elektrot Sudan III'ün elektrokimyasal davranışını araştırmak için kullanılmıştır. Nanoyapı modifiye edilmiş elektrodun karakterizasyonu için ise EIS ve DPV teknikleri uygulanmıştır (Şekil 3). Nano yapılı modifiye elektrot, Sudan III'ün oksidasyon pik akımı üzerinde mükemmel bir elektrokatalitik özellik göstermiştir. Sudan III'ün çinko oksit nanopartiküller ile modifiye edilmiş CPE'nin, ZnONPs / CPE yüzeyindeki elektrokimyasal davranışı DPV, CV ve Kronokulometri ile incelenmiştir. Optimize edilmiş koşullarda, Sudan III için doğrusal dinamik aralıklar $0,05-1,0$ ve $1,0-15,0 \mu \mathrm{M}$ olarak belirtilmiş ve modifiye elektrotlar ile $2,56 \mathrm{nM}$ tayin sınırına ulaşıldığı rapor edilmiştir. Önerilen biyosensör, kırmızı biber ve ketçap sos örneklerinde Sudan III'ün tespiti için başarıyla uygulanmıştır.

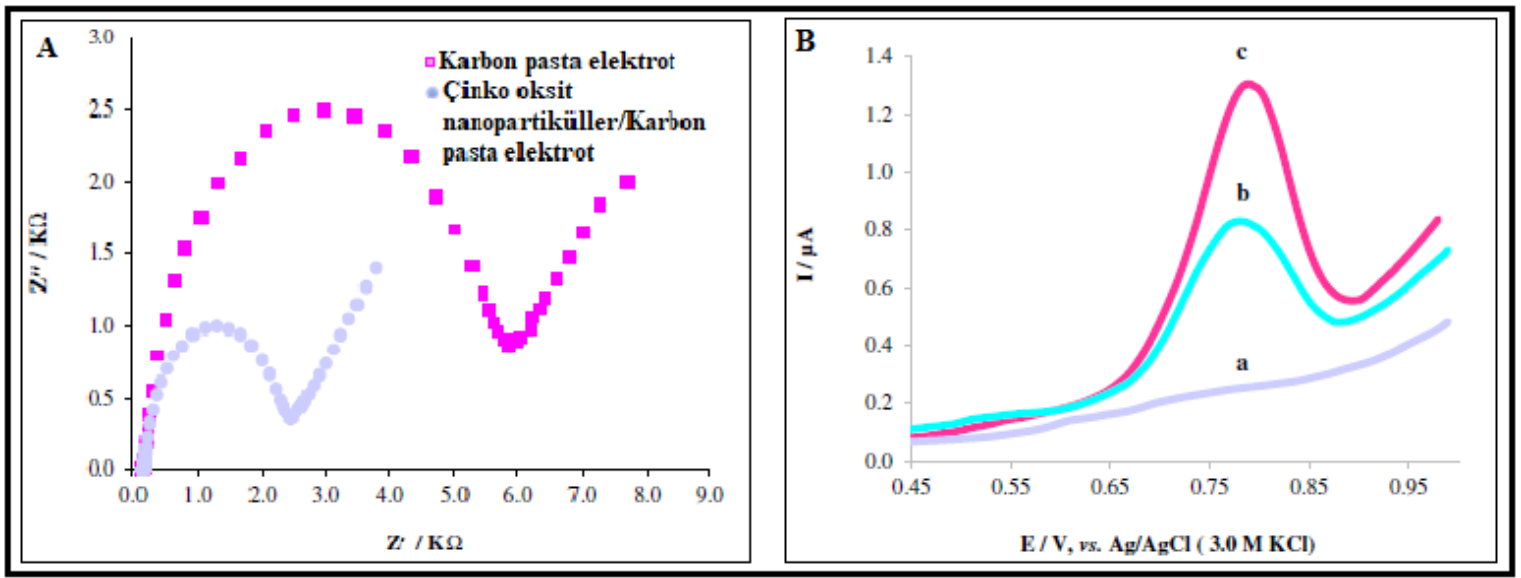

Şekil 3. (A) Yalın CPE ve ZnONPs/CPE nin $5.0 \mathrm{mM}\left[\mathrm{Fe}(\mathrm{CN})_{6}\right]^{3-/ 4-}$ içeren $\mathrm{pH}=7.0$ fosfat tamponu içindeki Nyquist eğrileri; (B) (a) ZnONPs/CPE nin pH: 4.2 fosfat tamponunda, (b) CPE'nin $5.0 \mu \mathrm{M}$ Sudan III varlığında, (c)

ZnONPs/CPE'nin $5.0 \mu \mathrm{M}$ Sudan III varlığında alınmış diferansiyel puls voltamogramları (Heydari ve ark., 2019)

\section{Ambalaj Malzemesi Ürünlerinin Bileşenleri, Hayvancılık Artıkları ve Gıdaların İşlenmesi Sırasında Oluşabilen Toksik Bileşiklere Yönelik Uygulamalar}

Bisfenol A, toksisitesi ve çevrede yaygın olarak bulunması nedeniyle en tehlikeli endokrin bozuculardan biridir ve çok sayıda bileşiğin üretim proseslerinde hammadde olarak büyük ölçüde kullanılmaktadır. Ambalaj malzemesi olarak kullanılan plastik esaslı şişeler, güneş ışığına maruz kaldığında içme suyuna bisfenol A salınır. Bu sebeple insan ve çevre sağlığı için içme suyunda bisfenol A'nın hızlı ve yerinde tespiti önemli bir konudur (Jemmeli ve ark., 2020). Enzimatik olmayan bisfenol A tespiti için Jemmeli ve ark. (2020), yeni ve uygun maliyetli, baskılı bir elektrokimyasal sensör geliştirmişlerdir. Bu sensör, reaktif içermeyen, filtre kağıdına basılmış tüm elektrokimyasal hücreyi ve selüloz fiber ağa yüklenen ölçüm için reaktifleri kapsar. ÇaIışma elektrodu, hassas ve sürdürülebilir bisfenol $A$ tayini için uygun maliyetli bir nanomateryal olan karbon siyahı ile modifiye edilmiş mürekkep kullanılarak basılmıştır. $\mathrm{pH}$, frekans ve genlik dahil olmak üzere çeşitli parametreler, elektrokimyasal teknik olarak Kare Dalga Voltametri kullanılarak $0,1-0,9 \mu \mathrm{M}$ ve $1 \mu \mathrm{M}-$ $50 \mu \mathrm{M}$ olmak üzere iki doğrusal aralıkla ve $0,03 \mu \mathrm{M}$ 'lik bir tayin sınırına imkan verecek şekilde optimize edilmiştir. Geliştirilen kağıt bazlı sensördeki bir çip üzerindeki laboratuvarda bisfenol A kantifikasyonu için yalnızca $\mu \mathrm{L}$ boyutunda numunenin eklenmesi gerekmektedir. Nehir ve içme suyu örneklerinde bulunan tatmin edici geri kazanım değerleri, bu sensörün su numunelerindeki tarama analizleri için uygunluğunu göstermiştir. 
Bakteriyel kökenli antibiyotikler, insan ve veterinerlik tıbbında yaygın olarak kullanılmaktadır. Birçok hastalığın tedavisinde devrim niteliğinde olan antibiyotik tedavisinin en başından beri aşırı ilaç kullanımı veya kötüye kullanımının bir sonucu olarak antimikrobiyal direnç ile sonuçlandığı bilinmektedir. İnsan sağlığının yanı sıra, et ve sütün antibiyotik kontaminasyonu, fermantasyon süreci üzerindeki istenmeyen etkiler ve tüketicinin vücudundaki olası birikim nedeniyle ekonomik kayıplara neden olabilir. Süt ineklerinde mastitis tedavisinden başlayarak antibiyotikler modern hayvancılık sektörünün vazgeçilmez bir parçası haline gelmiştir. Bir aminoglikozid antibiyotik olan kanamisin A (KANA) da bu antibiyotiklerden biridir ve Avrupa Birliği'ne göre sütteki maksimum kalıntı seviyesi (MRL), $150 \mu \mathrm{g} / \mathrm{kg}$ olmalıdr. Plazmadaki yüksek KANA seviyeleri, işitme ve denge sorunlarına, renal toksisiteye ve hatta aminoglikozidlere alerjisi olan kişilerde nöromüsküler blokaja neden olabilmektedir. Çeşitli antibiyotiklerle artan süt ve et kontaminasyon seviyeleri, yiyecek ve sudaki antibiyotik kalıntılarının yerinde değerlendirilmesi için basit ve güvenilir analitik cihazların geliştirilmesini gerektirmektedir Kulikova ve ark. (2020). Bir kitosan matris içinde karbon siyahının biriktirilmesi ve ardından bir koni içinde tiakaliks arenin oligolaktid türevi ile karıştırılmış amine aptamerin karbodiimid bağlanması ile camımsı karbon elektrot yüzeyinde KANA'nın belirlenmesine yönelik geliştirilen impedimetrik bir aptasensör çalışmasında CV, EIS ve SEM teknikleri kullanılmıştır. KANA mevcudiyetinde, iç arayüzün yük aktarım direnci, 0,7 ve $50 \mathrm{nM}$ aralığındaki analit konsantrasyonu ile şaşırtıcı bir şekilde azalmıştır ve tayin sınırı 0,3 nM olarak elde edilmiştir. Tasarlanan aptasensör, \%95 ve \%115 geri kazanımları ile süt ve yoğurt örneklerinde KANA tayininde başarıyla test edilmiştir (Kulikova ve ark., 2020).

Akrilamid, hayvanlar için potansiyel olarak kanserojen olan bir nörotoksindir. İşlenmiş gıdalarda, öncelikle karbonhidrat erişimli bir gıda kızartıldığında veya pişirildiğinde oluşan Maillard Reaksiyonu'nun bir yan ürünüdür (Navarro ve ark., 2020). Akrilamidin saptanmasına yönelik yapılan bir çalışmada, basit bir CPE üzerinde duyarlı ve düşük maliyetli bir biyosensör hazırlanmıştır. Bu tasarımda, hemoglobin başlangıçta, bir kitosan tabakası ile demir manyetik nanopartiküllerden oluşan hibrit bir nanokompozit üzerine sabitlenmiştir. Nanokompozit/hemoglobin, bir biyosensör üretmek için karbon pasta ile karıştırılmıştır. Hazırlanan sensör, sırasıyla \%4,14 ve \%4,68 bağıl hatalarla tekrarlanabilirlik ve tekrar üretilebilirlik sunmuştur. Kalibrasyon eğrisi, 10 ile $171 \mathrm{nmol} / \mathrm{L}$ arasında değişen akrilamid konsantrasyonları için doğrusallık sunmuştur $\left(R^{2}=0,9945\right)$. Tayin sınırı 0,06 nmol/L olup analitik geri kazanım de- ğerleri \%90,8 ile \%102,6 arasında olduğu belirlenmiştir. Önerilen biyosensör ayrıca Fransız kızartmalarındaki akrilamidin tayini için başarıyla kullanılmıştır. Bu sonuçlar, hazırlanan sensörün, gıdalardaki akrilamid seviyelerini izlemek için uygun olan basit ve duyarlı olduğunu göstermektedir (Navarro ve ark., 2020).

\section{SONUÇ}

Bu derlemede gıda kontaminasyonlarına yönelik elektrokimyasal biyosensör uygulamaları hakkında örnekler verilmiştir. Çeşitli gıda kirleticilerinin sebep olduğu kontaminasyonlar sonucu gıda güvenliği ve insan sağlığını olumsuz yönde etkilenmektedir. Kontaminasyonlar sonucu ortaya çıkan gıda tehlikelerinin tespit edilip önlenmesi adına kalitatif ve kantitatif olmak üzere GC ve HPLC gibi analiz metodlarının yanı sıra çeşitli biyosensör tekniklerinin de aralarında bulunduğu birçok analiz yöntemi geliştirilmiştir. Biyosensör teknikleri sağladıkları birçok avantaj sayesinde son yıllarda daha çok tercih edilen yöntemlerden olmuştur. En eski ve en gelişmiş biyosensör çeşitlerinden olan elektrokimyasal biyosensörlerin düşük duyarlılık, yüksek tekrarlanabilirlik, hızlı yanıt, düşük maliyet, minyatürleştirilebilme, kolay çalışılabilme, taşınabilme ve bu sayede yerinde analize olanak sağlama gibi çeşitli avantajları sayesinde, gıda kontaminasyon analizlerinde kullanılan geleneksel yöntemlere alternatif haline gelmiştir. Elektrokimyasal biyosensörlerin avantajları göz önünde bulundurulduğunda gelecekte bu biyosensörlerin daha fazla geliştirilerek ticarileştirilmesi ve gerçek numune uygulanmalarının yaygınlaşacağı öngörülmektedir.

\section{KAYNAKLAR}

Aghoutane, Y., Diouf, A., Österlund, L., Bouchikhi, B., El Bari, N. (2020). Development of a molecularly imprinted polymer electrochemical sensor and its application for sensitive detection and determination of malathion in olive fruits and oils. Bioelectrochemistry, 132: 107404; DOI: 10.1016/j.bioelechem.2019.107404

Alahi, M.E.E., Mukhopadhyay, S.C. (2017). Detection methodologies for pathogen and toxins: A review. Sensors (Switzerland), 17(8): 1-20.

Bahadır, E.B., Pagano, S.M. (2014). Pestisit Analizlerinde Elektrokimyasal Biyosensörlerin Kullanımı. Ömer Halisdemir Üniversitesi Mühendislik Bilim Dergisi, 3(2): 18-28.

Belitz, H.D., Grosch, W., Schieberle, P. (2009). Food Chemistry. Springer, Heidelberg, Germany.

Boz, B., Paylan, İ.C., Kizmaz, M.Z., Erkan, S. (2017). Biyosensörler ve Tarım Alanında Kullanımı. Tarım Makinaları Bilimi Dergisi, 13(3): 141-148.

Caglayan, M.O., Şahin, S., Üstündağ, Z. (2020). Detection Strategies of Zearalenone for Food Safety: A Review. Critical Reviews in Analytical Chemistry; DOI: 
10.1080/10408347.2020.1797468

Chen, Y., Qian, C., Liu, C., Shen, H., Wang, Z., Ping, J., Wu, J., Chen, H. (2020). Nucleic acid amplification free biosensors for pathogen detection. Biosensors and Bioelectronics,153: 112049; DOI: 10.1016/j.bios.2020.112049

Ding, J., Liu, Y., Zhang, D., Yu, M., Zhan, X., Zhang, D., Zhou, P. (2018). An electrochemical aptasensor based on gold@polypyrrole composites for detection of lead ions. Microchimica Acta, 185: 545; DOI: 10.1007/s00604018-3068-Z

Doğan, Y., Koç, F. (2018). Gıdalarda Kimyasal Kalıntılar ve Analiz Metotları. Erciyes Üniversitesi Veterinerlik Fakültesi Dergisi, 15(3): 264-270.

Erkmen, O. (2010). Gida kaynakli tehlikeler ve güvenli gida üretimi. Çocuk Sağlığı ve Hastalıkları Dergisi, 53 (3): 220-235.

Evtugyn, G., Hianik, T. (2019). Electrochemical immuno- and aptasensors for mycotoxin determination. Chemosensors, $\quad 7$ : $10 ; \quad$ DOI: 10.3390/chemosensors7010010

Feng, N., Zhang, J., Li, W. (2019). Chitosan/Graphene Oxide Nanocomposite-Based Electrochemical Sensor For ppb Level Detection of Melamine. Journal of the Electrochemical Society, 166 (14): 1364-1369.

Fernández, B.P., Mercader, J.V., Fuentes, A.A., Orrego, B.I.C., García, A.C., Muñiz, A.E. (2020). Direct competitive immunosensor for Imidacloprid pesticide detection on gold nanoparticle-modified electrodes. Talanta, 209: 120465; DOI: 10.1016/j.talanta.2019.120465

Fu, J., Yao, Y., An, X., Wang, G., Guo, Y., Sun, X., Li, F. (2020). Voltammetric determination of organophosphorus pesticides using a hairpin aptamer immobilized in a graphene oxide-chitosan composite. Microchimica Acta, 187(1): 36; DOI: 10.1007/s00604019-4022-4

Geleta, G.S., Zhao, Z., Wang, Z. (2018). Electrochemical Biosensors for Detecting Microbial Toxins by Graphene-Based Nanocomposites. Journal of Analysis and Testing, 2: 20-25.

Güner, A., Çevik, E., Şenel, M., Alpsoy, L. (2017). An electrochemical immunosensor for sensitive detection of Escherichia coli 0157:H7 by using chitosan, MWCNT, polypyrrole with gold nanoparticles hybrid sensing platform. Food Chemistry, 229: 358-365.

Güler, Ü.A., Can, Ö.P. (2017). Kimyasal Kontaminantların Çevre Sağlığı ve Gıda Güvenliği Üzerine Etkileri. Sinop Üniversitesi Fen Bilimleri Dergisi, 195: 170-195.

Helali, S., Sawelem, A., Alatawi, E., Abdelghani, A. (2018). Pathogenic Escherichia coli biosensor detection on chicken food samples. Journal of Food Safety, 38: 12510; DOI: 10.1111/jfs. 12510

Heydari, M., Ghoreishi, S.M., Khoobi, A. (2019). Response Surface Modeling of Electrochemical Data for Sensitive Determination of Sudan III in Food Products at the Surface of a Nanocomposite Modified Electrode. Food Analytical Methods, 12(8): 1781-1790.

Jayan, H., Pu, H., Sun, D.W. (2020). Recent development in rapid detection techniques for microorganism activities in food matrices using bio-recognition: A review. Trends in
Food Science and Technology, 95: 233-246.

Jemmeli, D., Marcoccio, E., Moscone, D., Dridi, C., Arduini, F. (2019). Highly sensitive paper-based electrochemical sensor for reagent free detection of bisphenol A. Talanta, 216: 120924; DOI: 10.1016/j.talanta.2020.120924

Jiang, D., Geb, P., Wang, L., Jiang, H., Yang, M., Yuan, L., Geb, Q., Fang, W., Jua, X., (2019). A novel electrochemical mast cell-based paper biosensor for the rapid detection of milk allergen casein. Biosensors and Bioelectronics, 130: 299-306.

Kaneko, N., Horii, K., Akitomi, J., Kato, S., Shiratori, I., Waga, I. (2018). An aptamer-based biosensor for direct, labelfree detection of melamine in raw milk. Sensors (Switzerland), 18(10): 3227; DOI: 10.3390/s18103227

Karapetis, S., Nikolelis, D., Hianik, T. (2018). Label-free and redox markers-based electrochemical aptasensors for aflatoxin M1 detection. Sensors (Switzerland), 18 (12): $1-14$.

Koç, F. (2018). Gıdalarda Kimyasal Kalıntılar ve Analiz Metotları. Erciyes Üniversitesi Veterinerlik Fakültesi Dergisi, 13(3): 264-271.

Kozitsina, A.N., Svalova, T.S., Malysheva, N.N., Okhokhonin, A.V., Vidrevich, M.B., Brainina, K.Z. (2018). Sensors based on bio and biomimetic receptors in medical diagnostic, environment, and food analysis. Biosensors, 8(2): 1-34.

Kuchmenko, T.A., Lvova, L.B. (2019). A perspective on recent advances in piezoelectric chemical sensors for environmental monitoring and foodstuffs analysis. Chemosensors, 7(3): 14-17.

Kulikova, T., Gorbatchuk, V., Stoikov, I., Rogov, A., Evtugyn, G., Hianik, T. (2020). Impedimetric determination of kanamycin in milk with aptasensor based on carbon black-oligolactide composite. Sensors (Switzerland), 20(17): 1-17.

Kurbanoglu, S., Erkmen, C., Uslu, B. (2020). Frontiers in electrochemical enzyme based biosensors for food and drug analysis. Trends in Analytical Chemistry, 124: 115809; DOI: 10.1016/j.trac.2020.115809

Le, A.V.T., Su, Y.L., Cheng, S.H. (2019). A novel electrochemical assay for aspartame determination via nucleophilic reactions with caffeic acid ortho-quinone. Electrochimica Acta, 300: 67-76.

Liang, G., Man, Y., Jin, X., Pan, L., Liu, X. (2016). Aptamerbased biosensor for label-free detection of ethanolamine by electrochemical impedance spectroscopy. Analytica Chimica Acta, 936: 222-228.

Li, Y. (2006). Hardware, in CIGR Handbook of Agricultural Engineering Information Technology. CIGR Handbook of Agricultural Engineering, VI: 52-93.

Li, Y., Liu, H., Huang, H., Deng, J., Fang, L., Luo, J., Zhang, S., Huang, J., Liang, W., Zheng, J. (2020). A sensitive electrochemical strategy via multiple amplification reactions for the detection of $E$. coli O157: $\mathrm{H} 7$. Biosensors and Bioelectronics, 147: 111752; DOI 10.1016/j.bios.2019.111752

Li, Z., Li, X., Jian, M., Geleta, G.S., Wang, Z. (2019). TwoDimensional Layered Nanomaterial-Based Electrochemical Biosensors for Detecting Microbial Toxins. Toxins, 12(20): 1-23.

Moro, G., De Wael, K., Moretto, L.M. (2019). Challenges in 
the electrochemical (bio)sensing of nonelectroactive food and environmental contaminants. Current Opinion in Electrochemistry, 16: 57-65.

Nardi, V.A.M., Teixeira, R., Ladeira, W.J., Santini, F.O. (2020). A meta-analytic review of food safety risk perception. Food Control, 112: 107089; DOI: 10.1016/j.foodcont.2020.107089

Navarro, K.M., Silva, J.C., Ossick, M.V., Nogueira, A.B., Etchegaray, A., Mendes, R.K. (2020). Low-Cost Electrochemical Determination of Acrylamide in Processed Food Using a Hemoglobin-Iron Magnetic Nanoparticle-Chitosan Modified Carbon Paste Electrode. Analytical Letters, 1-13.

Nielsen, S.S. (2017). Food Analysis. Springer, ChamSwitzerland.

Nodoushan, S.M., Nasirizadeh, N., Amani, J., Halabian, R., Fooladi, A.A.I. (2018). An electrochemical aptasensor for staphylococcal enterotoxin $B$ detection based on reduced graphene oxide and gold nano-urchins. Biosensors and Bioelectronics, 127: 221-228.

Nogués, M.H., Oliu, S.B., Abramova, N., Muñoz, F.X., Bratov, A., Moruno, C.M., Gil, F.J. (2016). Impedimetric antimicrobial peptide-based sensor for the early detection of periodontopathogenic bacteria. Biosensors and Bioelectronics, 86: 377-385.

Paepe, E.D., Wauters, J., Borght, M.V.D., Claes, J., Huysman, S., Croubels, S., Vanhaecke, L. (2019). Ultrahigh-performance liquid chromatography coupled to quadrupole orbitrap high-resolution mass spectrometry for multi-residue screening of pesticides, (veterinary)drugs and mycotoxins in edible insects. Food Chemistry, 293: 187-196.

Pan, M., Liu, K., Yang, J., Hong, L., Xie, X., Wang, S. (2020). Review of research into the determination of acrylamide in foods. Foods, 9(4): 524; DOI: 10.3390/foods9040524

Panhwar, S., Hassan, S.S., Mahar, R.B., Carlson, K., Rajput, M.H., Talpur, M.Y. (2019). Highly Sensitive and Selective Electrochemical Sensor for Detection of Escherichia coli by Using L-Cysteine Functionalized Iron Nanoparticles. Journal of the Electrochemical Society, 166(4): 227-235.

Saldamlı, İ. (2014). Gıda Kimyası. Hacettepe Üniversitesi Yayınları, Ankara-Türkiye.

Soon, J.M., Brazier, A.K.M., Wallace, C.A. (2020). Determining common contributory factors in food safety incidents - A review of global outbreaks and recalls 2008-2018. Trends in Food Science \& Technology, 97:76-87.

Thyparambil, A.A., Bazin, I., Guiseppi-Elie, A. (2017). Molecular Modeling and Simulation Tools in the
Development of Peptide-Based Biosensors for Mycotoxin Detection: Example of Ochratoxin. Toxin, 9: 395; DOI 10.3390/toxins9120395

Tüylek, Z. (2017). Biyosensörler ve Nanoteknolojik Etkileşim. Bitlis Eren Üniversitesi Fen Bilimleri Dergisi 6(62): 71-80.

Wang, S., Sun, C., Hu, Q., Li, S., Wang, C., Wang, P., Zhou, L. (2020). A homogeneous magnetic bead-based impedance immunosensor for highly sensitive detection of Escherichia coli O157:H7. Biochemical Engineering Journal, 156: 107513; DOI: 10.1016/j.bej.2020.107513

Wang, W., Xu, Y., Cheng, N., Xie, Y., Huang, K., Xu, W. (2020). Dual-recognition aptazyme-driven DNA nanomachine for two-in-one electrochemical detection of pesticides and heavy metal ions. Sensors and Actuators B: $\quad$ Chemical, 321: 128598; DOI: 10.1016/j.snb.2020.128598

Wang, Y., Ning, G., Bi, H., Wu, Y., Liu, G., Zhao, Y. (2018). A novel ratiometric electrochemical assay for ochratoxin A coupling $\mathrm{Au}$ nanoparticles decorated MoS2 nanosheets with aptamer. Electrochimica Acta, 285: 120-127.

Williams, P. (2012). Food toxicity and safety. Essentials of Human Nutrition, Oxford-England.

Wu, Q., Zhang, Y., Yang, Q., Yuan, N., Zhang, W. (2019). Review of electrochemical DNA biosensors for detecting food borne pathogens. Sensors (Switzerland), 19(22): 4916; DOI: 10.3390/s19224916

Xu, X., Ying, Y. (2011). Microbial biosensors for environmental monitoring and food analysis. Food Reviews International, 27(3): 300-329.

Yang, D., Liu, X., Zhou, Y., Luo, L., Zhang, J., Huang, A., Mao, Q., Chen, X., Tang, L. (2017). Aptamer based biosensors for detection of lead(ii) ion a review. Analytical Methods, 9: 1976-1990.

Ye, Y., Ji, J., Sun, Z., Shen, P., Sun, X. (2020). Recent advances in electrochemical biosensors for antioxidant analysis in foodstuff. TrAC - Trends in Analytical Chemistry, 122: 115718; DOI: 10.1016/j.trac.2019.115718

Zhang, Y., Zhang, C., Ma, R., Du, X., Dong, W., Chen, Y., Chen, Q. (2017). An ultra-sensitive Au nanoparticles functionalized DNA biosensor for electrochemical sensing of mercury ions. Materials Science and Engineering $C$, 75: 175-181.

Zhou, X., Pu, H., Sun, D.W. (2020). DNA functionalized metal and metal oxide nanoparticles: principles and recent advances in food safety detection. Critical Reviews in Food Science and Nutrition, 1-20; DOI: 10.1080/10408398.2020.1809343 